\title{
STRATEGY FOR DEVELOPMENT OF PALM OIL MILL CONTRACTOR SERVICES
}

\author{
Sitepu Hendra Maga Putra*, Sjarief Rizal, Sahara \\ School of Business, Bogor Agricultural University, Indonesia \\ *E-mail: hendramagap@gmail.com
}

\begin{abstract}
Palm oil production is supported by a palm oil mill, where oil palm mills are required to produce high hours of production. One of the business sectors that support the utility of palm oil mills is a contracting services company. PT SMI is a company engaged in the business of contracting services that focuses on the maintenance and repair of tools and machinery in palm oil mills. The tight competition between contractor service companies, because North Sumatra is a palm oil center, so that it affects the decrease in the amount of PT SMI's revenue. The method in determining the main strategy can be done through three stages of implementation, namely the stage of data collection (evaluation of internal and external factors), the matching stage (IE and SWOT matrices), and the decision stage (QSPM matrix). The results of this study are based on three strategic priorities, namely first to carry out maintenance and repair in existing palm oil mills and prepare installations for waste management in palm oil mills. Second, form a part of the marketing team to carry out the promotion and outreach agenda related to the maintenance, repair and management of palm oil mill waste and to collaborate with the North Sumatra environmental department (DLH). Third, socializing the utilization of palm oil liquid waste to palm oil mills to open new market opportunities in North Sumatra.
\end{abstract}

\section{KEY WORDS}

Contractor, external, internal factor evaluation, palm oil mill.

Production of vegetable oil sourced from palm oil plants has higher production compared to vegetable oil sourced from other plants (GAPKI 2016). The contribution of the Indonesian palm oil industry can be one of the factors driving investment that attracts investors' attention along with the increase in world population growth, where demand for palm oil continues to increase (World Growth Report, 2011). According to BPS (2018), the number of plantation companies from 2015 to 2017 showed an increase of 287 units or $19 \%$. The increase was also followed by the amount of palm oil production increased from 2015 to 2017, amounting to 4.2 million tons or $13 \%$. The increase in the number of palm oil companies in Indonesia in the last few years is followed by an increase in the amount of palm oil production (CPO). Palm oil mills (PKS) are an integrated part of oil palm plantation companies which are increasingly growing oil palm plantation companies.

Palm oil production is supported by a palm oil mill, where oil palm mills are required to produce high hours of production. This condition is caused when FFB is not treated immediately it can trigger an increase in free fatty acid levels (Pahan 2008). Loss of production due to damage to tools and machinery can cause losses for palm oil mill companies in terms of production costs and repair costs are high (Yuhelson, 2010). Maintenance activities need to be carried out to prevent production failures due to equipment and machine damage. According to Corder and Hadi (1992) the purpose of machine / equipment maintenance activities in general includes two things: (1) Condition maintenance and (2) Replacement maintenance. One of the business sectors that support the utility of palm oil mills is a contracting services company.

PT SMI is one of the companies engaged in the business of contracting services that focuses on maintenance and repair in palm oil mills. The development of the palm oil industry shows that there has been an increase in the number of oil palm plantation companies in recent years. The increase in the number of oil palm plantation companies can create competition for other contractor service companies that are newcomers, but can also 
be a business opportunity for PT SMI. This makes PT SMI must be able to compete with other similar contracting companies, so it needs to have the right development strategy. Based on the data in Table 1 shows that there is an increase in the number of contractor service companies in North Sumatra in small and medium groups. PT SMI is currently included in the middle business group, where the position of the middle business group in 2012 number of companies amounted to 578 units and increased in 2016 by 1282 units. This makes the competition for PT SMI tight with other contractor companies because it is the central area of oil palm.

Table 1 - Number of contractor service companies in North Sumatra 2012-2016

\begin{tabular}{cccccc}
\hline Business group & \multicolumn{5}{c}{ Year } \\
\cline { 2 - 6 } & 2012 & 2013 & 2014 & 2015 & 2016 \\
\hline Small & 5387 & 5259 & 5816 & 6509 & 8575 \\
Intermediate & 578 & 592 & 656 & 745 & 1282 \\
Big & 100 & 92 & 104 & 23 & 38 \\
\hline Total & 6065 & 5943 & 6576 & 7277 & 9895 \\
\hline
\end{tabular}

Source: BPS (2017) (processed).

In Figure 1 shows the income of PT SMI from 2012 to 2017. The company's activities in the contracting services business at the palm oil mill were initially quite good, so that it can be seen in 2014 to 2016 the company's revenue has increased. However, in the last year the company experienced a significant decrease in the amount of company revenue in 2017 (Figure 2). The condition of the company can be seen by evaluating the internal and external environment of PT SMI to be able to improve the company's ability to see opportunities and minimize the company's weaknesses and make appropriate decisions.

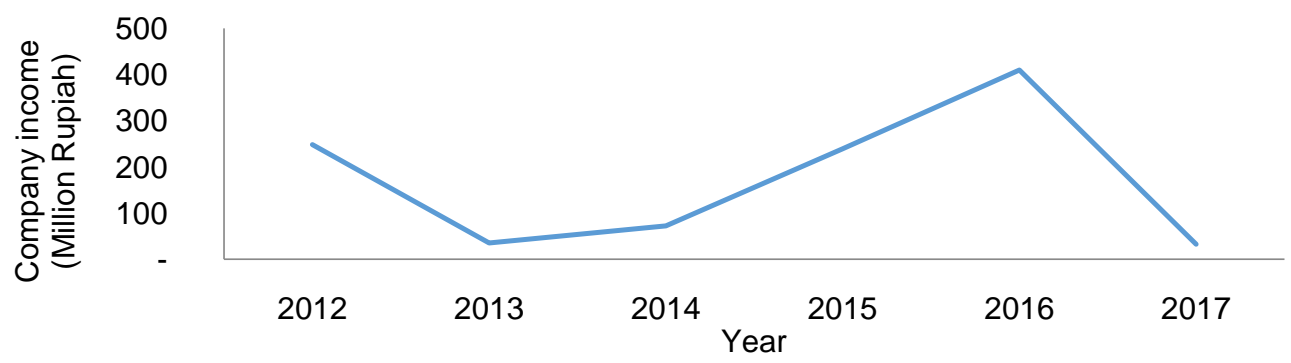

Figure 1 - PT SMI's revenue graph from 2012 to 2017

One of the external environments in PT SMI is the intense competition between contractor service companies, which can be seen in Table 2, where North Sumatra is a palm oil center, thus affecting the decline in the amount of company revenue. These conditions make PT SMI needs to have a corporate strategy. By establishing a strategy, it is expected to produce a decision-making step for the company's future and business development, and be able to compete with other contractor service companies and be able to seize the opportunities that exist in the palm oil industry. Based on these conditions, the formulation of the problem that is the focus of this research is about the internal and external factors that influence the business development of PT SMI, formulate alternative strategies from PT SMI, priorities for developing PT SMI's palm oil processing contractor service business. Based on the description of the background and formulation of the problem, the purpose of this study is as follows identify the influence of internal and external factors that affect the business development of PT SMI, develop alternative strategies that fit PT SMI's environmental conditions, establish priorities of business development strategies that can be applied by PT SMI. The results of this study are expected to benefit the authors, PT SMI and readers as follows, for the writer, get practical experience on how to formulate business services business development contractor services, especially in the palm oil industry, for PT SMI, it will obtain input on designing a development strategy that can be used for the decision making process related to the development of the business sector in the midst of business 
competition in contractor company services, for readers it can be used as a source of information and literature review material for further research related to business development strategies. This research was conducted at PT SMI by involving internal management and external parties related to the contracting services business. This research is limited to the study of business contractor service development strategies at PT SMI. In this study the aspects analyzed are internal and external aspects of the company by making IFE and EFE matrices, alternative formulation of strategies using IE and SWOT matrices and management decision making using quantitative strategic planning matrix (QSPM) methods whose priorities are left to PT SMI's internal parties.

\section{LITERATURE REVIEW}

Research conducted by Amin (2018) entitled Strategic Business Model Planning Services Architecture Consultant Services and Contractor Services PT Architectaria Media Cipta in his research was conducted to map the business models that are used today by preparing business plans, strategic programs that are appropriate to seize opportunities to face challenges and business competition in the future. The analytical tools used are IFE, EFE, SWOT analysis, BMC and BOS. The SWOT analysis results show that there are internal and external factors that are the strengths and weaknesses of the company in running its business model. There are seven elements that must be repaired major and two elements that are repaired minor. Managerial implications of the results of the study recommend nine important pins that must be carried out and are key to the sustainability of PT AMC's business model in the future.

Research conducted by Laksono (2016) titled Development Strategy for Oil Palm Plantation Agribusiness Companies (Case Study of PT Bumitama Gunajaya Agro). The purpose of this study was to determine the competitive advantage of PT Bumitama Gunajaya Agro (PT BGA) to develop the company and analyze and formulate an appropriate business development strategy for PT BGA in the palm oil industry today. The analytical tool used in this study is the analysis of IFE, EFE, IE, and QSPM. The internal factors of PT BGA include the ability to get optimal sales margins, technological inventories, good reputation, access to raw materials, and the ability to motivate and build a family relationship between employees. While the external factors of PT BGA are the application of environmentally friendly operational practices, opportunities to develop the CPO business in the biodiesel sector, environmental issues, a moratorium on the opening of oil palm concessions and the impact of price fluctuations. The position of PT BGA on the IE matrix is to maintain and maintain.

Research conducted by Lubis (2017) titled Strategy for Improving Supply Chain Management Performance in Sei Galuh Palm Oil Mill of PT Perkebunan Nusantara V. Identifying and analyzing the structure and role of supply chain networks in PKH SGH, measuring supply chain performance using supply chain operation reference (SCOR) methods ), as well as formulating strategies to improve supply chain performance in the $\mathrm{PKH}$ $\mathrm{SGH}$. The analytical tool used in this study is the score model, FGD, and AHP. The results of the analysis of the supply chain structure show that there are three supply chain structures in the PKH SGH. The main objective achieved by PKS SGH is to improve supply chain performance by increasing the productivity of machinery and equipment. These objectives can be achieved by implementing an integrated machine and equipment repair planning strategy.

Research conducted by Nayantakaningtyas (2012) entitled Competitiveness and Development Strategy for Palm Oil in Indonesia, aims to analyze Indonesian CPO products on the international market and analyze strategies to improve Indonesia's CPO competitiveness. The analytical tool used in this study is Revealed Comparative Advantages (RCA) and Diamond Porter's theory. The method in knowing the development strategy of this study uses a SWOT analysis. The results obtained from this study through an analysis tool using RCA and Berlian Porter's theory are known that Indonesia's CPO competitiveness is quite strong, but there needs to be a strategy to strengthen CPO derivative products. 
Research conducted by Joni (2016) entitled The Impact of the Development of the Biodiesel Industry from Palm Oil on Palm Oil Plantations and the Palm Oil Industry in Indonesia aims to formulate policy implications based on the results of an analysis of the impact of the development of biodiesel from palm oil on the palm oil industry, palm oil plantations and the palm cooking oil industry in Indonesia. In this study a simulation was conducted to determine the impact of policies on oil palm plantations, the palm oil industry and the downstream palm oil industry in Indonesia through the development of the biodiesel industry from palm oil. The simulation results can be used to formulate the best policy for the development of biodiesel from palm oil. The simulation shows that an increase in government spending, an increase in export taxes and a decrease in interest rates will have a higher positive impact on oil palm plantations, the palm oil industry and the downstream palm oil industry but an increase in export taxes can reduce the area of oil palm plantations.

Subakti (2017) in his research entitled analysis of strategic objectives and implementation of a balanced scorecard of oil palm plantation companies. The object of this research was conducted at the National Prime Example (TPG) which is one of the national oil palm plantation companies in Indonesia. The purpose of this study was to analyze the company's strategic objectives by using a pairwise comparison analysis technique of 14 strategic objectives in the four perspectives of the BSC TPG through the analytic network process (ANP) process.

\section{METHODS OF RESEARCH}

This research was conducted at PT SMI, located in Medan City, North Sumatra. This research was conducted in March 2019. This study uses two types of data, namely primary data and secondary data. Primary data is done with a descriptive approach and data collection is done to answer problems related to research. Descriptive approach aims to describe the facts of certain problems factually and systematically. Information was obtained from respondents by conducting observations and interviews from internal parties of PT SMI. Secondary data obtained from documents owned by the company, literature, theses, journals, articles, books and from other sources.

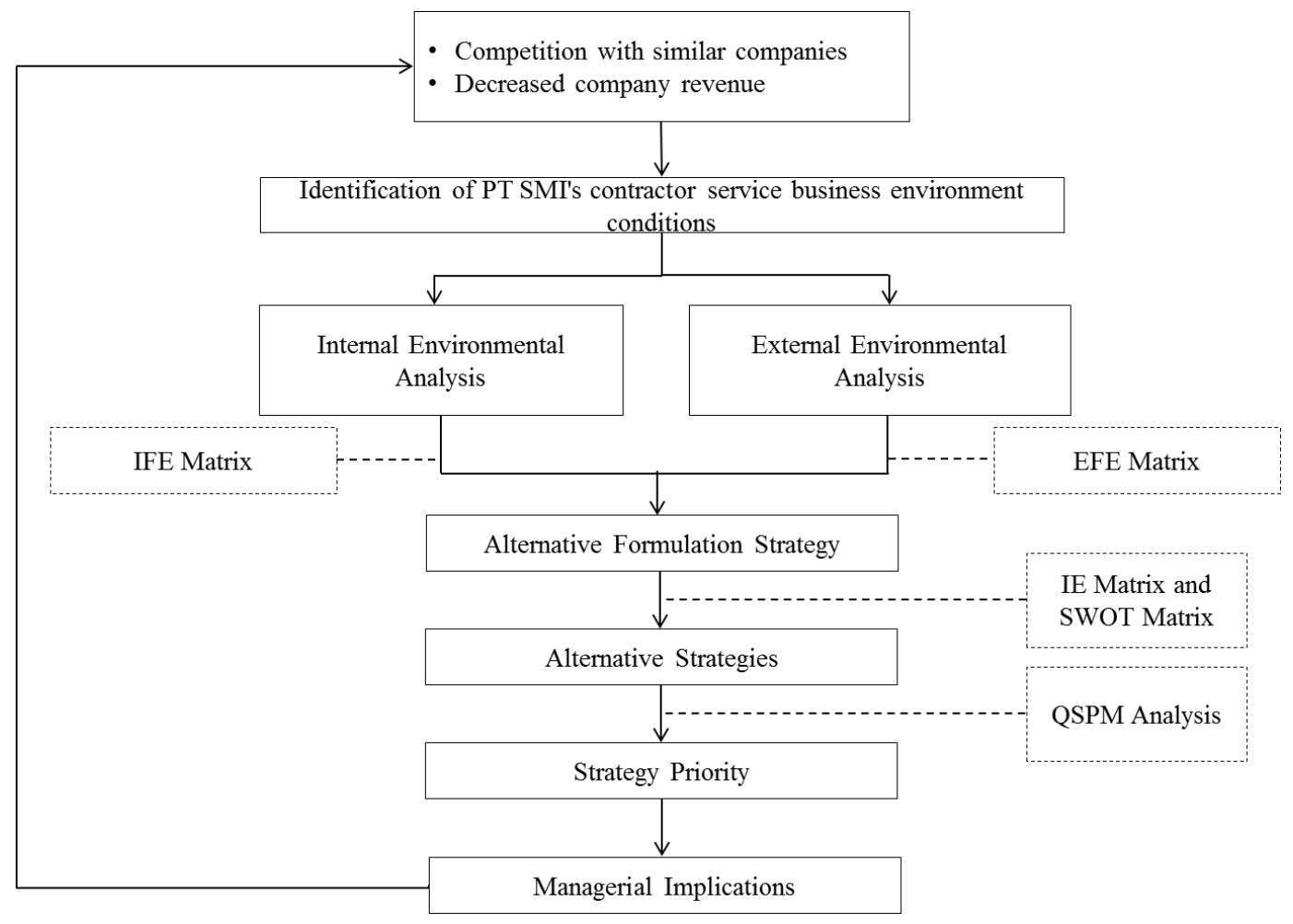

Figure 2 - Conceptual Thinking Framework 


\section{RESULTS AND DISCUSSION}

The analysis used in this study begins with the identification of internal and external factors from PT SMI. Data was collected through in-depth interviews with decision makers involved in improving the development of palm oil mill contractor services in PT SMI. Internal factor values can be seen in Table 2 .

Table 2 - Matrix Internal Factor Evaluation (IFE)

\begin{tabular}{|c|c|c|c|}
\hline Indicator & Weight & Rating & Total \\
\hline \multicolumn{4}{|l|}{ STRENGTH } \\
\hline Asset ownership & 0.13 & 3 & 0.39 \\
\hline Company project portfolio & 0.15 & 4 & 0.61 \\
\hline Has a strategic location & 0.10 & 3 & 0.30 \\
\hline Availability of company capital & 0.15 & 4 & 0.60 \\
\hline WEAKNESS & & & \\
\hline Don't have ISO 9001 certification & 0.11 & 2 & 0.22 \\
\hline Limited tools and technology & 0.08 & 1 & 0.08 \\
\hline The lack of supervision of the work & 0.10 & 1 & 0.10 \\
\hline The absence of a company SOP & 0.12 & 2 & 0.23 \\
\hline The marketing methods are not good yet & 0.07 & 1 & 0.07 \\
\hline TOTAL & 1.00 & & 2.60 \\
\hline
\end{tabular}

Based on internal strategic factor calculations, the main strength of PT SMI is the company's project portfolio. This is indicated by a score of 0.61 . The strategic factor which is the main weakness is the marketing method that has not been good, which has a score of 0.07 . While the minor weakness factor is the absence of a company SOP that has a score of 0.23. The total score from the IFE Matrix is 2.60 . The results of the analysis of internal factors can be seen in Table 2.

Table 3 - Matrix External Factor Evaluation (EFE)

\begin{tabular}{|c|c|c|c|}
\hline Indicator & Weight & Rating & Total \\
\hline \multicolumn{4}{|l|}{ OPPORTUNITIES } \\
\hline Growth in oil palm production area in northern Sumatra & 0.14 & 3 & 0.41 \\
\hline Utilization of palm oil waste & 0.15 & 4 & 0.61 \\
\hline The potential of the palm oil industry is still high & 0.13 & 4 & 0.50 \\
\hline Government policy regarding CPO & 0.13 & 3 & 0.39 \\
\hline \multicolumn{4}{|l|}{ THREAT } \\
\hline Implementation of health, safety, and environment (HSE) in evers & & & \\
\hline in the construction sector & 0.14 & 2 & 0.28 \\
\hline Competition between contractor companies in the palm oil center & 0.08 & 1 & 0.08 \\
\hline High interest rates & 0.11 & 1 & 0.11 \\
\hline Limited amount of material purchases from suppliers & 0.13 & 1 & 0.13 \\
\hline TOTAL & 1.00 & & 2.51 \\
\hline
\end{tabular}

The highest value of the opportunity factor for utilization of palm oil liquid waste is 0.61 . The minor opportunity factor in the EFE matrix is the government policy on CPO, which is 0.39 , which means the smallest opportunity expected by PT SMI. While the main threat factor is competition among contracting companies in the palm oil center of 0.08 which means that this factor is the biggest threat in the business development of PT SMI. A minor threat factor is the adoption of e-procurement in the tender system. With a total IFE matrix score of 2.51 .

Based on the EFE and IFE values of 2.68 and 2.43 , the IE matrix produced at PT SMI is in cell position 5. According to David (2009), the right strategy to answer this result is a strategy that is held and maintained, as launched market and product development.

Combining internal and external factors through the stages of analysis in the SWOT matrix will produce alternative strategies for business development from PT SMI. The SWOT matrix itself will produce 4 main strategies, namely: SO (Strengths-Opportunities) Strategy, ST (Strengths-Threats) Strategy, WO (Weeknesess-Opportunities) Strategy and WT (Weeknesses-Threats) Strategy (Rangkuti 2014). As can be seen in Table 4 which are 
alternative strategies derived from the SWOT matrix analysis of PT SMI's business development.

Table 4 - SWOT Matrix PT SMI

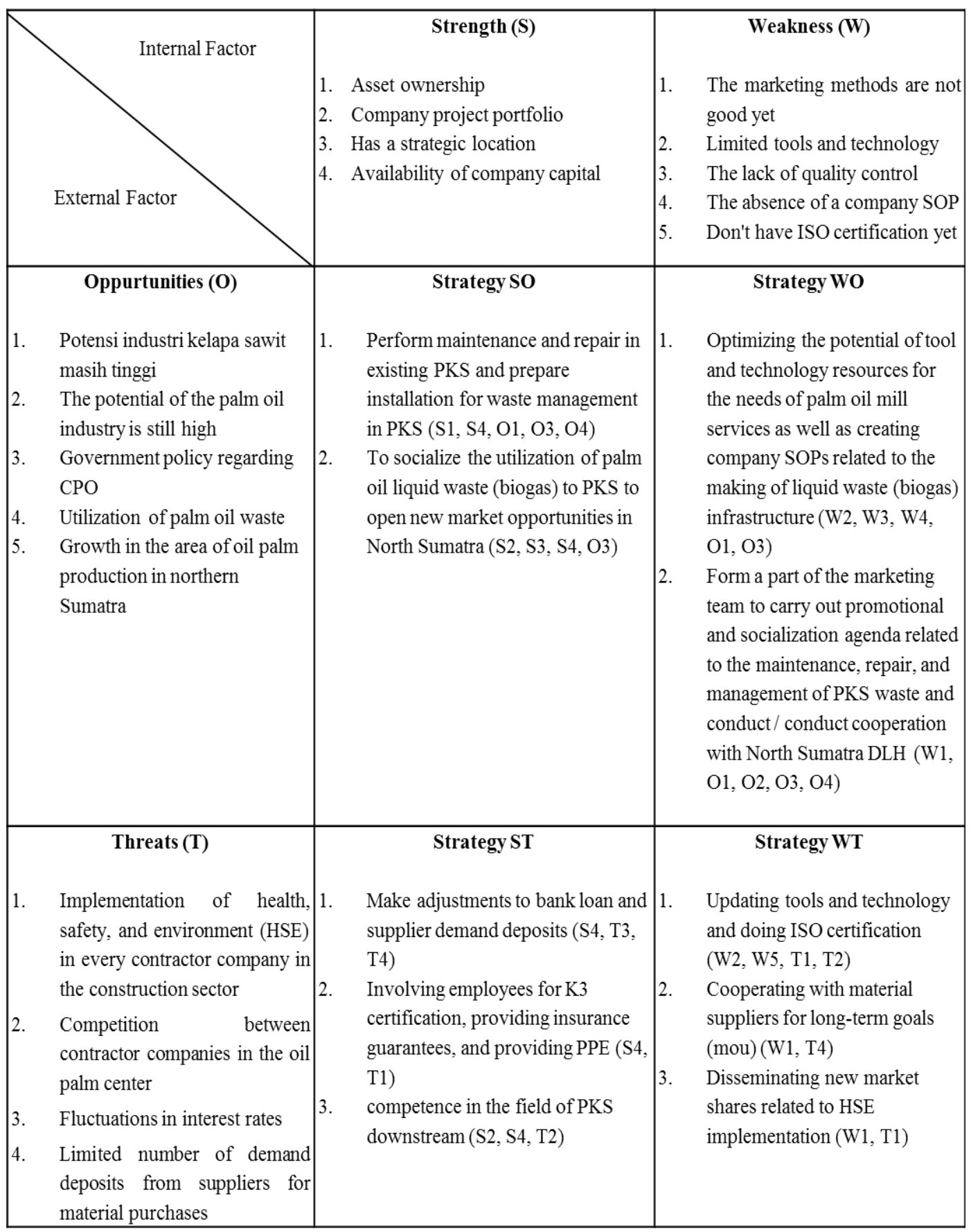

The quantitative strategic planning matrix (QSPM) method produces strategic priorities including: first is to carry out maintenance and repairs in existing PKS and to prepare installations for waste treatment in PKS, second is to form part of the marketing team to carry out promotional and socialization agendas related to the maintenance, repair and management of PKS waste and conduct / collaborate with the North Sumatra environmental department (DLH), and the third is to disseminate the utilization of palm oil (biogas) waste to PKS to open new market opportunities in North Sumatra. 


\section{CONCLUSION}

Based on the identification of internal factors from PT SMI produced four strength factors and five weakness factors. The main strength factor owned by the company is the company's project portfolio, while the minor strength factor is having a strategic location. The main weakness factor of PT SMI is the marketing method that has not been good, while the minor weakness factor of the company is the absence of company SOPs. The results of the identification of the external factors of PT SMI's business produced four opportunity factors and four threat factors. The main opportunity factor of PT SMI is the utilization of palm oil liquid waste, while the minor opportunity factor of the company is the government policy regarding CPO. The main threat factor that needs to be considered by the company is competition among contractor companies in the palm oil center, while the company's minor threat factor is the application of health, safety, and environment (HSE) to every contractor company in the construction sector.

The results of the analysis of the preparation of alternative strategies using the IE matrix method show that PT SMI is in quadrant $\mathrm{V}$ (hold and maintain), where the right strategy in responding to the IE results is by carrying out market penetration and product development. The results of the analysis of the preparation of alternative strategies using the SWOT matrix method at PT SMI produced eleven alternative strategies, including conducting maintenance and repairs in existing PKS and preparing installations for waste treatment in PKS, socializing the utilization of palm oil liquid waste (biogas) to PKS to open new business opportunities in North Sumatra, optimize the resources of tools and technology that are potential for the needs of PKS services and create SOPs for the manufacture of liquid waste infrastructure (biogas), form part of the marketing team to carry out promotional and socialization agenda related to maintenance, repair, and management of PKS waste as well as collaborating with the North Sumatra environmental department (DLH), making adjustments to bank loan loans and material expenditure from suppliers, involving employees for K3 certification, providing insurance guarantees, and using PPE, making supply suit competencies in the downstream field of PKS, updating tools and technology and standardizing company SOPs and ISO 9001 certification, collaborating with material suppliers for long-term goals (mou), and conducting socialization to new market share related to HSE implementation.

Determination of strategic priorities by using the QSP (Quantitative Strategic Planning) matrix method at PT SMI produces eleven strategic priorities, but the main focus of the company is the three priority strategies which take precedence, namely the first is to perform maintenance and repairs in existing PKS and prepare installations for the treatment of liquid waste in PKS. PT SMI has had experience and competence in the palm oil industry specifically to handle the care and repair of palm oil mills so it needs to maintain good relations with each of its customers. Preparation for the installation of palm oil liquid waste is also an opportunity for PT SMI to develop its business, so it is necessary to prepare the needs for the process of the installation of liquid waste. The second strategic priority is to form part of the marketing team to carry out promotional and socialization agendas related to the maintenance, repair, and management of PKS waste as well as conduct / collaborate with the North Sumatra environmental department (DLH) and the third priority is to disseminate the utilization of palm oil liquid waste ( biogas) to PKS to be able to reach the market on the development of these service products.

\section{RECOMMENDATIONS}

In this study, suggestions that can be given based on the results of research conducted related to the development of PT SMI are as follows:

1. The development of PT SMI must be carried out by implementing alternative strategies produced so that PT SMI can increase its income by carrying out maintenance and repairs at the existing palm oil mill (customer) and preparing an installation for the management of liquid waste in PKS; 
2. Form a part of the marketing team to carry out promotional and socialization agendas related to the maintenance, repair, and management of PKS waste and conduct / conduct cooperation with DLH North Sumatra;

3. To socialize the utilization of palm oil liquid waste (biogas) to PKS to open new market opportunities in North Sumatra;

4. For further research, it is necessary to develop business from the downstream sector of palm oil liquid waste as a producer of electrical energy so that it becomes an added value for oil palm plantation companies and conduct research on marketing electricity from palm oil liquid waste to the community.

\section{REFERENCES}

1. Badan Pusat Statistik. 2016. Direktori Perusahaan Perkebunan Sawit. Jakarta (ID): BPS.

2. Badan Pusat Statistik. 2017. Direktori Perusahaan Perkebunan Sawit. Jakarta (ID): BPS.

3. Badan Pusat Statistik. 2018. Direktori Perusahaan Perkebunan Sawit. Jakarta (ID): BPS.

4. Corder dan Hadi. 1992. Teknik Manajemen Pemeliharaan. Jakarta: Penerbit Erlangga.

5. David FR. 2013. Manajemen Strategis. Jakarta: Penerbit Salemba Empat.

6. [GAPKI] Gabungan Pengusaha Kelapa Sawit Indonesia. 2016. Keunggulan komparatif kelapa sawit sebagai minyak nabati dunia [Internet]. [Diakses pada 2018 November 19]. Tersedia pada https://gapki.id/news/1690/keunggulan-komparatif-kelapa-sawit-sebagai minyak-nabati-dunia.

7. Laporan World Growth Februari. 2011. Manfaat minyak sawit bagi Perekonomian Indonesia. Palm Oil Green Development Campaign. [Internet]. [Diakses pada 2018 November 06]. Tersedia pada http://worldgrowth.org/site/wpcontent/uploads/2012/06/WG_Indonesian_PalmOil_Benefit s_Bahasa_Report-2_11.pdf

8. Pahan. 2008. Kelapa Sawit: Manajemen Agribisnis dari Hulu hingga Hilir. Cetakan I. Jakarta (ID): Penebar Swadaya.

9. Yuhelson. 2010. Analisis Reliability Dan Availability Mesin Pabrik Kelapa Sawit PT Perkebunan Nusantara 3. Jurnal Dinamis. 2(6): 6-22. 